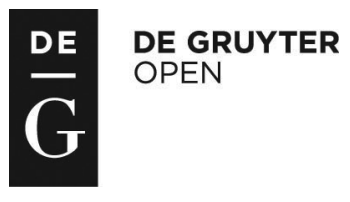

\title{
IMPACTS OF DISTILLER'S DRIED GRAINS WITH SOLUBLES AS REPLACEMENT OF SOYBEAN MEAL PLUS VITAMIN E SUPPLEMENTATION ON PRODUCTION, EGG QUALITY AND BLOOD CHEMISTRY OF LAYING HENS
}

\author{
Muhammad Saeed ${ }^{1}$, Mohamed E. Abd El-Hack ${ }^{2}$, Muhammad Arif ${ }^{3}$, Mohamed M. El-Hindawy², \\ Adel I. Attia ${ }^{2}$, Khalid M. Mahrose ${ }^{2}$, Itrat Bashir ${ }^{4}$, Farman A. Siyal ${ }^{5}$, Muhammad A. Arain ${ }^{6}$, \\ Sarfraz Ali Fazlani ${ }^{6}$, Khawar Hayat ${ }^{1}$, Chao Sun $^{1 *}$, Ahmed E. Noreldin ${ }^{7}$
}

\author{
${ }^{1}$ College of Animal Sciences, Northwest A\&F University, Yangling 712100, China \\ ${ }^{2}$ Department of Poultry, Faculty of Agriculture, Zagazig University, Zagazig 44511, Egypt \\ ${ }^{3}$ Department of Animal Sciences, University College of Agriculture, University of Sargodha, 40100, Pakistan \\ ${ }^{4}$ Department of Zoology, University of the Punjab, 54590 Pakistan \\ ${ }^{5}$ Department of Animal Nutrition, Faculty of Animal Husbandry and Veterinary Sciences, \\ Sindh Agriculture University Tando Jam, 70060 \\ ${ }^{6}$ Faculty of Veterinary and Animal Sciences, Lasbela University of Agriculture Water and Marine \\ Sciences Uthal, Pakistan, 3800 \\ ${ }^{7}$ Department of Histology and Cytology, Faculty of Veterinary Medicine, Damanhour University, \\ Damanhour, Egypt \\ •Corresponding authors: Chao Sun: sunchao2775@163.com, Mohamed E. Abd El-Hack: m.ezzat@zu.edu.eg
}

\begin{abstract}
The present investigation aimed to study the effect of the partial replacement of distiller's dried grains with solubles (DDGS) instead of soybean meal (SBM) with or without vitamin E supplementation in laying hen diet on egg quality criteria, egg analysis, blood chemistry and productive performance traits. A $4 \times \mathbf{2}$ factorial design experiment was carried out involving four substitution levels of DDGS (0, 25, 50 and 75\%) and two levels of vitamin $E(0$ and $250 \mathrm{mg} / \mathrm{kg}$ diet) through 22-42 weeks of age. No significant differences were noticed between the control and 25 or $50 \%$ DDGS substitution in the percentage of eggs produced and egg output. The fewest number of produced eggs and the lightest egg output were observed in 75\% DDGS group. Yolk index, shell percentage, and Haugh unit scores were affected $(\mathrm{P}>0.01)$ by DDGS levels. Albumin percentage showed increase $(\mathrm{P}>\mathbf{0 . 0 1})$ in vitamin $\mathrm{E}$ treated groups. The impact of the combination of DDGS and vitamin $E$ was significant $(P>0.01)$ on all egg quality traits excepting shell percentage. The 75\% DDGS diet gave the highest values of egg nutrients. Vitamin $\mathbf{E}$ had a positive effect on egg crude protein, ether extract, and nitrogen free extract which increased by 10.39, 10.28 and $7.85 \%$, respectively. The combination of vitamin $E$ addition and DDGS levels was highly significant $(P>0.01)$ on all egg nutrients. Hens fed the 50\% DDGS diet had more concentrations of lipids profile in their blood than those fed control and other DDGS diets. All serum lipid profile inclined to increase due to vitamin $\mathbf{E}$ supplementation. The interaction between DDGS and vitamin $\mathbf{E}$ had significant $(\mathrm{P}>\mathbf{0 . 0 5}$ or $\mathbf{0 . 0 1})$ influence on all serum metabolites excepting calcium. It could be concluded that vitamin $\mathbf{E}$ could enhance nutrient content of eggs and preserve blood lipids from lipid peroxidation. The interaction between 75\% DDGS replaced SBM with $200 \mathrm{mg}$ vitamin E/kg diet accomplished the best results regarding nutrient content of eggs.
\end{abstract}

Key words: DDGS, vitamin E, layers, production, egg quality, egg analysis, blood metabolites 
Soybean meal has been deemed as a prominent source of supplemental protein in diets for poultry and livestock. Actually, soybean meal is mentioned as the "gold standard" because of its comparison with the other protein sources. Soybean meal is characterized by its high content of the digestible protein, and the protein is composed of a predominant mixture of amino acids, the building blocks of body protein for poultry and livestock. However, the price of this ingredient hit an all-time record high. Thus, there is an urgent need for affordable and nutritious alternative feed. The best strategy for cost reduction is the expansion of diet formulation using locally available ingredients, alternative, thereby lowering feed cost (Laudadio and Tufarelli, 2011; Abd El-Hack, 2015). Distiller's dried grains with solubles - the by-product of the ethanol industry - is a valuable source of protein and sulphur amino acids and was used at 50-200 g/ kg inclusion concentrations in diets, even as a source of onethird of protein supply, without affecting performance (AAFCO, 2002; Świątkiewicz et al., 2013; Abd El-Hack et al., 2015 a, b; Sun et al., 2015). A favorable effect on some egg quality parameters had been seen by distiller's dried grains with solubles (Jensen et al., 1978). Recently, the growth of fuel ethanol production has increased the availability of DDGS for feed producers. The high nutritional quality of DDGS obtained from modern ethanol technology qualifies the usage of this feed material on a large scale in poultry nutrition, as the most environmentally-friendly way of using DDGS (Świątkiewicz et al., 2014). Vitamin E is well-known to be an essential chain-breaking antioxidant which usually is used in poultry diets to make use of its beneficial impacts to laying hens during heat stress (Gallo-Torres, 1980; Abd El-Hack, 2015). As reported, vitamin E protects tissues and cells from oxidative damage which is induced by free radicals (Naziroglu et al., 2000). Aljamal et al. (2008) reported that supplementing diets of White Bovans hens with 50 IU of vitamin E/kg enhanced feed intake compared with those fed the control diet El-Mallah et al. (2011) pointed out that Hisex Brown laying hens fed diets supplemented with vitamin E $(40 \mathrm{mg} / \mathrm{kg})$ had statistical improvement in egg yield percentage being $84.75 \%$ comparing with the control which was $82.65 \%$. The relationship between vitamin $A$ and vitamin $E$ has been studied that can be explained as vitamin $E$ has a critical impact on the utilization and absorption of vitamin A. In addition, vitamin $\mathrm{E}$, as antioxidant, protects and prevents vitamin A from oxidative breakdown induced by heat stress (Gallo-Torres, 1980). Little information is available about the impact of vitamin E supplement in diets containing DDGS on laying hens. So, the study hypothesized that vitamin E - as a natural antioxidant - may enhance productive performance of laying hens fed DDGS, which involve high level of polyunsaturated fatty acids which are susceptible to lipid peroxidation. In addition, DDGS has a high rate of oils (about 10\%) with easy fermentable unsaturated fatty acid composition. The present study investigated the influences of vitamin E supplementation in diets containing graded levels of DDGS on productive performance, egg quality criteria, egg analysis and blood chemistry within the experimental period. 


\section{Material and methods}

\section{Experimental design, birds, and diets}

The present study was conducted at the Poultry Research Farm, Poultry Department, Faculty of Agriculture, Zagazig University, Zagazig, Egypt. All procedures of the experiment were performed according to the Local Experimental Animal Care Committee and approved by the ethics of the institutional committee of Poultry Department, Faculty of Agriculture, Zagazig University, Zagazig, Egypt.

A total of 120 Hisex Brown laying hens, 22 weeks old, were indiscriminately divided into 8 treatment groups of 15 hens $(5$ replicates/treatment and 3 hens/replicate). Each replicate was housed in one layer cage. Hens of all experimental groups had nearly the same initial average body weight (1620 $2.54 \mathrm{~g})$ and were not statistically different. A $4 \times 2$ factorial design experiment was performed including four levels of DDGS $(0,5.5,11$ and $16.5 \%$ replaced for the same percent of SBM which represents $0,25,50$ and $75 \%$, respectively in the diet) and two levels of vitamin $E$ ( 0 and $250 \mathrm{mg} / \mathrm{kg}$ diet) through 22-42 weeks of age.

Eight isonitrogenous and isocaloric diets were formulated to cover the nutrient requirements of laying hens from 22-42 weeks of age according to NRC (1994). DDGS used in the experiment contained $89.05 \%$ dry matter, $95.38 \%$ organic matter, $4.62 \%$ ash, $27.23 \%$ crude protein, $11.27 \%$ ether extract, $7.45 \%$ crude fiber and $38.48 \%$ nitrogen free extract which determined according to AOAC (2003). Vitamin E used in this study was in the form of dl- $\alpha$-tocopherol acetate and purchased from Multivita Company, Sixth of October City, Egypt. Chemical analysis and composition of the experimental diets are shown in Table 1.

Table 1. Ingredients and chemical analysis of diets fed to laying hens

\begin{tabular}{|c|c|c|c|c|c|}
\hline \multirow{2}{*}{ Items } & \multicolumn{5}{|c|}{ Soybean meal replacement by DDGS (\%) } \\
\hline & 0 & 25 & 50 & 75 & 100 \\
\hline 1 & 2 & 3 & 4 & 5 & 6 \\
\hline \multicolumn{6}{|l|}{ Components (\%) } \\
\hline corn & 60.58 & 59.46 & 58.30 & 57.20 & 56.02 \\
\hline DDGS $(27 \%)$ & 0.00 & 5.50 & 11.00 & 16.50 & 22.00 \\
\hline soybean meal (44\%) & 22.00 & 16.50 & 11.00 & 5.50 & 0.00 \\
\hline corn gluten meal $(62 \%)$ & 4.92 & 6.39 & 7.85 & 9.31 & 10.77 \\
\hline limestone & 8.17 & 8.19 & 8.23 & 8.27 & 8.34 \\
\hline dicalcium phosphate & 1.85 & 1.83 & 1.80 & 1.75 & 1.70 \\
\hline mineral premix ${ }^{1}$ & 0.15 & 0.15 & 0.15 & 0.15 & 0.15 \\
\hline vitamin premix ${ }^{2}$ & 0.15 & 0.15 & 0.15 & 0.15 & 0.15 \\
\hline $\mathrm{NaCl}$ & 0.30 & 0.30 & 0.30 & 0.30 & 0.30 \\
\hline DL-Methionine & 0.12 & 0.10 & 0.09 & 0.07 & 0.05 \\
\hline L-Lysine $\mathrm{HCl}$ & 0.04 & 0.13 & 0.23 & 0.32 & 0.42 \\
\hline soybean oil & 1.72 & 1.30 & 0.90 & 0.48 & 0.10 \\
\hline \multirow{2}{*}{\multicolumn{6}{|c|}{$\begin{array}{l}\text { Chemical analysis: } \\
\text { a-Calculated }{ }^{3}:\end{array}$}} \\
\hline & & & & & \\
\hline $\mathrm{ME}(\mathrm{kcal} / \mathrm{kg}$ diet $)$ & 2850 & 2850 & 2851 & 2851 & 2852 \\
\hline
\end{tabular}


Table 1 - contd.

\begin{tabular}{l|r|r|r|r|r}
\hline \multicolumn{1}{c|}{1} & \multicolumn{1}{c|}{2} & \multicolumn{1}{c|}{3} & \multicolumn{1}{c|}{4} & \multicolumn{1}{c}{5} & 6 \\
\hline crude protein (\%) & 18.00 & 18.00 & 18.00 & 18.00 & 18.00 \\
calcium (\%) & 3.64 & 3.64 & 3.64 & 3.64 & 3.64 \\
available P (\%) & 0.45 & 0.45 & 0.45 & 0.45 & 0.45 \\
methionine+cystine (\%) & 0.75 & 0.75 & 0.75 & 0.75 & 0.75 \\
lysine (\%) & 0.84 & 0.84 & 0.84 & 0.84 & 0.84 \\
crude fiber (\%) & 2.94 & 3.05 & 3.16 & 3.27 & 3.37 \\
b- Determined ${ }^{4}$ (\%): & & & & & \\
crude protein (\%) & 18.16 & 18.26 & 17.91 & 17.76 & 18.01 \\
crude fat (\%) & 5.17 & 5.54 & 5.52 & 5.49 & 5.80 \\
ash (\%) & 5.46 & 5.04 & 4.95 & 5.16 & 5.30 \\
\hline
\end{tabular}

${ }^{1}$ Layer mineral premix: each $1.5 \mathrm{~kg}$ consists of Mn, $60 \mathrm{~g}$; Zn, $50 \mathrm{~g}$; Cu, 10 g; I, 1000 mg; Si, $100 \mathrm{mg}$; Co, $1000 \mathrm{mg}$.

${ }^{2}$ Layer vitamin premix: each $1.5 \mathrm{~kg}$ consists of: Vit. A, $12000 \mathrm{IU}$; Vit. D, $2000 \mathrm{ICU}$, Vit. E, 10 g; Vit. K, 328 mg; Vit. $B_{1}, 1000 \mathrm{mg}$; Vit. $\mathrm{B}_{2}, 5000 \mathrm{mg}$; Vit. $\mathrm{B}_{6}, 1500 \mathrm{mg}$, Vit. $\mathrm{B}_{12}, 10 \mathrm{mg}$; biotin, $50 \mathrm{mg}$; pantothenic acid, $10 \mathrm{~g}$; niacin, $30 \mathrm{~g}$; folic acid, $1000 \mathrm{mg}$.

${ }^{3}$ Calculated according to NRC (1994).

${ }^{4}$ Analyzed according to AOAC (2003).

\section{Management}

The feed and the fresh water for birds were available ad libitum during the experimental period. The artificial light source was used beside the natural light giving a total of 16 hours of light per day during the experimental period. Medical program and vaccinations were performed according to the stages of age under the supervision of a veterinarian.

\section{Data collection}

Eggs were daily collected and egg production percentage was calculated on as a percent of hen-day basis. Egg number and egg weight were registered daily to calculate the egg output (egg number $\times$ egg weight). Daily feed intake was recorded and calculated as grams of feed disappearance over $7 \mathrm{~d}$ divided by the number of bird days, adjusted for mortalities, while feed efficiency (g egg/g feed) was calculated as the amount of feed consumed divided by the egg mass.

Egg quality parameters were monthly measured using three eggs from each replicate. Eggs were weighed and then egg length and width were measured before breaking. The egg was cautiously cracked on a glass plate $(35 \times 25 \mathrm{~cm})$ to measure egg quality traits. Yolks were detached from albumen. Eggshell was cleaned of any agglutinated albumen and albumen weight was calculated by subtracting the weight of yolk and shell from the whole egg weight. Egg shape indices were computed as the ratio of egg width to the length (Awosanya et al., 1998). Yolk height was measured by means of tripod micrometer reading to the nearest $0.01 \mathrm{~mm}$ while yolk diameter was measured by vernier caliper to the nearest $0.05 \mathrm{~mm}$. Haugh unit score was computed according to the formula suggested by Singh and Kumar (1994).

Five eggs from each treatment group were randomly collected at the end of the experiment (42 weeks of age) for measuring whole solids and chemical composition 
of the whole eggs. The yolk and albumen were mixed with shell after breaking egg and homogenate into an aluminum dish. The sample was weighed before introducing into the oven. Egg samples were dried for 24 hours at $60^{\circ} \mathrm{C}$ to eliminate primary moisture, then samples were dried in an oven for 3 hours at $105^{\circ} \mathrm{C}$ to eliminate secondary moisture, and then weighed. The proximate analysis of dried whole eggs and feed samples were carried out according to AOAC (2003) for determination of DM (ID 930.15), OM (ID 942.05), CP (ID 954.01), EE (ID 945.16) and CF (ID 978.10).

At the end of the experiment, blood samples were randomly collected from five birds per group and withdrawn from the brachial vein of the birds. Blood samples were centrifuged $(4000 \mathrm{rpm})$ for ten minutes and serum samples were kept in Eppendorf tubes at $-20^{\circ} \mathrm{C}$ until analysis. Triglycerides $(\mathrm{mg} / \mathrm{dl})$, total cholesterol $(\mathrm{mg} / \mathrm{dl})$, HDL-cholesterol (mg/dl), LDL-cholesterol (mg/dl), calcium (mg/dl) and phosphorus $(\mathrm{mg} / \mathrm{dl})$ levels were determined by using available commercial kits as described by the manufacturer companies (Spectrum Diagnostics, Egyptian Company for Biotechnology, SAE) as mentioned by Akiba et al. (1982).

\section{Statistical analysis}

Data were statistically analyzed on a $4 \times 2$ factorial design basis according to Snedecor and Cochran (1982) using SPSS ${ }^{\circledR}$ software statistical analysis program (IBM SPSS Statistics, ver. 22; USA). The Duncan's new multiple range test (Duncan, 1955) was used for comparison among significant means.

\section{Results}

\section{Hen productive performance}

Data presented in Table 2 showed that all productive performance traits were significantly ( $\mathrm{P}>0.05$ or 0.01$)$ impacted by graded levels of DDGS substituted for SBM. No significant differences were found between the control and 25 or $50 \%$ DDGS substitution in the percentage of egg produced as well as egg output within the experimental period. While the fewest number of produced eggs and the lightest egg output were observed in the group fed the highest level of DDGS replacement rate $(75 \%)$ compared with other treatment groups. The best feed efficiency was found in the control group, while the worst was given by the $75 \%$ DDGS group compared with other experimental groups (Table 2). Egg production percentage was not affected by vitamin $\mathrm{E}$ addition (Table 2$)$. Egg output was significantly $(\mathrm{P}>0.05)$ decreased by vitamin E supplementation. No statistical differences were obtained due to the interaction between DDGS levels and vitamin E addition (Table 2).

\section{Egg quality characteristics}

The effect of DDGS replacement level instead of SBM on egg quality traits is illustrated in Table 3. Shell percentage, yolk index, and Haugh unit scores were statistically $(\mathrm{P}>0.01)$ influenced as a result of DDGS levels. A gradual decrease in shell percentage, but also a gradual increase in yolk index and Haugh units were recorded due to DDGS substitution levels. 
Table 2. Productive performance of laying hens as impacted by DDGS levels, vitamin E and their combinations at 42 weeks of age

\begin{tabular}{|c|c|c|c|c|}
\hline & Items & $\begin{array}{c}\text { Egg production } \\
(\%)\end{array}$ & $\begin{array}{c}\text { Egg output } \\
(\mathrm{kg})\end{array}$ & $\begin{array}{l}\text { Feed efficiency } \\
\text { (g egg/g feed) }\end{array}$ \\
\hline \multicolumn{5}{|c|}{ DDGS (\%) } \\
\hline \multicolumn{2}{|l|}{0} & $90.73 \mathrm{a}$ & $9.58 \mathrm{a}$ & $0.60 \mathrm{a}$ \\
\hline \multicolumn{2}{|l|}{25} & 88.68 a & $9.51 \mathrm{a}$ & $0.57 \mathrm{ab}$ \\
\hline \multicolumn{2}{|l|}{50} & $87.92 \mathrm{a}$ & $9.13 \mathrm{a}$ & $0.56 \mathrm{~b}$ \\
\hline \multicolumn{2}{|l|}{75} & $81.63 \mathrm{~b}$ & $8.09 \mathrm{~b}$ & $0.51 \mathrm{c}$ \\
\hline \multicolumn{5}{|c|}{ Vitamin E (mg/kg diet) } \\
\hline \multicolumn{2}{|c|}{0.00} & 89.54 & $9.44 \mathrm{a}$ & 0.56 \\
\hline \multicolumn{2}{|c|}{200.0} & 84.94 & $8.71 \mathrm{~b}$ & 0.56 \\
\hline \multicolumn{5}{|c|}{ DDGS $\times$ Vitamin $\mathrm{E}$} \\
\hline \multirow[t]{2}{*}{0} & 0.00 & 92.55 & 9.76 & 0.60 \\
\hline & 200.0 & 88.91 & 9.40 & 0.60 \\
\hline \multirow[t]{2}{*}{25} & 0.00 & 91.08 & 10.00 & 0.58 \\
\hline & 200.0 & 86.27 & 9.01 & 0.56 \\
\hline \multirow[t]{2}{*}{50} & 0.00 & 90.36 & 9.44 & 0.55 \\
\hline & 200.0 & 85.49 & 8.83 & 0.57 \\
\hline \multirow[t]{2}{*}{75} & 0.00 & 84.18 & 8.57 & 0.52 \\
\hline & 200.0 & 79.08 & 7.62 & 0.51 \\
\hline \multirow{2}{*}{\multicolumn{2}{|c|}{$\begin{array}{l}\text { SEM }^{1} \\
\text { Two-way ANOVA }\end{array}$}} & 0.06 & 0.15 & 0.01 \\
\hline & & & P-value ${ }^{2}$ & \\
\hline \multicolumn{2}{|c|}{ DDGS } & 0.030 & $>0.000$ & $>0.000$ \\
\hline \multicolumn{2}{|c|}{ Vitamin E } & 0.080 & 0.010 & 0.953 \\
\hline \multicolumn{2}{|c|}{$\underline{\text { DDGS } \times \text { vitamin } \mathrm{E}}$} & 0.988 & 0.586 & 0.450 \\
\hline
\end{tabular}

Means in the same column within each classification bearing different letters are significantly different $(\mathrm{P}<0.05$ or 0.01$)$.

${ }^{1}$ SEM: standard error of the means.

${ }^{2}$ Overall treatment P-value.

All egg quality criteria were significantly $(\mathrm{P}>0.01)$ impacted by dietary vitamin $\mathrm{E}$ addition except shell percentage and yolk index which insignificantly improved. Albumin percentage showed statistical $(\mathrm{P}>0.01)$ increase in vitamin $\mathrm{E}$ treated groups. Whilst the other parameters declined in hens fed vitamin E enriched diet.

In the present study, the effect of the combination between DDGS levels and vitamin $\mathrm{E}$ addition was significant $(\mathrm{P}>0.01)$ on all egg quality traits excepting shell percentage. The interaction between 0\% DDGS substitution plus $200 \mathrm{mg}$ vitamin E/ $\mathrm{kg}$ diet gave the best value of albumin percentage $(67.41 \%)$ and the lowest value of yolk percentage $(22.45 \%)$ compared with other treatment groups. Supplementing the $75 \%$ DDGS diet with $200 \mathrm{mg}$ vitamin E/ $\mathrm{kg}$ provided the highest values of yolk index $(52.62 \%)$ and Haugh units $(90.70 \%)$ in comparison with other groups. The combination of 50 or $7 \%$ DDGS substitution with $0 \mathrm{mg}$ vitamin $\mathrm{E}$ achieved the best values of egg shape index $(80.07 \%)$ and yolk percent $(25.52 \%)$, respectively compared to other combinations. 
Table 3. Egg quality criteria of laying hens as impacted by DDGS levels, vitamin E and their combinations at 42 weeks of age

\begin{tabular}{|c|c|c|c|c|c|c|c|}
\hline \multicolumn{2}{|c|}{ Items } & $\begin{array}{l}\text { Egg shape } \\
\text { index }(\%)\end{array}$ & $\begin{array}{c}\text { Albumen } \\
\text { percentage } \\
(\%)\end{array}$ & \begin{tabular}{|c|} 
Yolk \\
percentage \\
$(\%)$
\end{tabular} & $\begin{array}{c}\text { Shell } \\
\text { percent } \\
(\%)\end{array}$ & $\begin{array}{c}\text { Yolk index } \\
(\%)\end{array}$ & $\begin{array}{c}\text { Haugh units } \\
\text { score }\end{array}$ \\
\hline \multicolumn{8}{|c|}{ DDGS (\%) } \\
\hline \multicolumn{2}{|l|}{0} & 78.18 & 65.34 & 22.88 & $13.62 \mathrm{a}$ & $49.65 \mathrm{~b}$ & $86.17 \mathrm{c}$ \\
\hline \multicolumn{2}{|l|}{25} & 79.19 & 63.91 & 23.43 & $12.67 \mathrm{~b}$ & $49.65 \mathrm{~b}$ & $87.36 \mathrm{~b}$ \\
\hline \multicolumn{2}{|l|}{50} & 79.39 & 64.27 & 23.16 & $12.56 \mathrm{bc}$ & $49.85 \mathrm{~b}$ & $87.65 \mathrm{~b}$ \\
\hline \multicolumn{2}{|l|}{75} & 79.31 & 63.93 & 23.99 & $12.08 \mathrm{c}$ & $50.90 \mathrm{a}$ & $89.47 \mathrm{a}$ \\
\hline \multicolumn{8}{|c|}{ Vitamin E (mg/kg diet) } \\
\hline \multicolumn{2}{|l|}{0.00} & $79.83 \mathrm{a}$ & $63.53 \mathrm{~b}$ & $23.81 \mathrm{a}$ & 12.66 & 49.95 & $88.58 \mathrm{a}$ \\
\hline \multicolumn{2}{|c|}{200.0} & $78.21 \mathrm{~b}$ & $65.20 \mathrm{a}$ & $22.92 \mathrm{~b}$ & 12.80 & 50.07 & $86.74 \mathrm{~b}$ \\
\hline \multicolumn{8}{|c|}{ DDGS $\times$ Vitamin $E$} \\
\hline \multirow[t]{2}{*}{0} & 0.00 & $80.06 \mathrm{a}$ & $63.27 \mathrm{~cd}$ & $23.32 \mathrm{bc}$ & 13.42 & $49.61 \mathrm{~cd}$ & $87.66 \mathrm{~cd}$ \\
\hline & 200.0 & $76.29 \mathrm{c}$ & $67.41 \mathrm{a}$ & $22.45 \mathrm{c}$ & 13.82 & $49.68 \mathrm{~cd}$ & $84.68 \mathrm{f}$ \\
\hline \multirow[t]{2}{*}{25} & 0.00 & $79.23 \mathrm{ab}$ & $64.45 \mathrm{bc}$ & $23.01 \mathrm{bc}$ & 12.54 & $49.90 \mathrm{c}$ & $89.44 \mathrm{ab}$ \\
\hline & 200.0 & $79.16 \mathrm{ab}$ & $63.36 \mathrm{~cd}$ & $23.84 \mathrm{~b}$ & 12.80 & $49.40 \mathrm{~cd}$ & 85.27 ef \\
\hline \multirow[t]{2}{*}{50} & 0.00 & $80.07 \mathrm{a}$ & $64.21 \mathrm{bcd}$ & $23.39 \mathrm{bc}$ & 12.40 & $51.11 \mathrm{~b}$ & 88.98 bc \\
\hline & 200.0 & $78.72 \mathrm{~b}$ & $64.33 \mathrm{bcd}$ & $22.94 \mathrm{bc}$ & 12.73 & $48.59 \mathrm{~d}$ & $86.31 \mathrm{de}$ \\
\hline \multirow[t]{2}{*}{75} & 0.00 & $79.95 \mathrm{a}$ & $62.19 \mathrm{~d}$ & $25.52 \mathrm{a}$ & 12.30 & $49.18 \mathrm{~cd}$ & $88.24 \mathrm{bc}$ \\
\hline & 200.0 & $78.67 \mathrm{~b}$ & $65.68 \mathrm{ab}$ & $22.46 \mathrm{c}$ & 11.86 & $52.62 \mathrm{a}$ & $90.70 \mathrm{a}$ \\
\hline \multicolumn{2}{|l|}{ SEM $^{1}$} & 0.24 & 0.34 & 0.21 & 0.13 & 0.25 & 0.39 \\
\hline \multicolumn{2}{|c|}{ Two-way ANOVA } & \multicolumn{6}{|c|}{ P-value ${ }^{2}$} \\
\hline \multicolumn{2}{|l|}{ DDGS } & 0.140 & 0.158 & 0.058 & $>0.000$ & 0.012 & $>0.000$ \\
\hline \multicolumn{2}{|c|}{ Vitamin E } & $>0.000$ & 0.002 & 0.004 & 0.417 & 0.674 & $>0.000$ \\
\hline \multicolumn{2}{|c|}{ DDGS $\times$ vitamin $\mathrm{E}$} & 0.001 & 0.002 & 0.001 & 0.277 & $>0.000$ & $>0.000$ \\
\hline
\end{tabular}

Means in the same column within each classification bearing different letters are significantly different $(\mathrm{P}<0.05$ or 0.01$)$.

${ }^{1}$ SEM: standard error of the means.

${ }^{2}$ Overall treatment P-value.

\section{Chemical analysis of whole egg}

The effect of DDGS replacement level on whole egg analysis is illustrated in Table 4. All egg components were statistically ( $\mathrm{P}>0.01)$ impacted by DDGS levels. It is obvious that the highest substitution level of DDGS gave the highest values of egg total solids, crude protein, ether extract and organic matter. While the greatest values of moisture and nitrogen free extract were found in $25 \%$ and the control groups, respectively.

Vitamin E supplementation to layer diet had a positive effect on egg content of crude protein, ether extract and nitrogen free extract which increased by $10.39,10.28$ and $7.85 \%$, respectively comparing with the diet free of supplemental vitamin E. At the same time, the highest values of total solids and moisture were noticed in eggs of hens fed diets supplemented with vitamin E.

As shown in Table 4, the impact of the combination of vitamin E addition and DDGS levels was highly significant $(\mathrm{P}>0.01)$ on all egg nutrients. The interaction between vitamin E plus the highest substitution level of DDGS (75\%) produced the 
best levels of egg total solids (30.56\%), crude protein $(13.39 \%)$ and ether extract (9.67\%) compared with other groups. The combination of $0 \mathrm{mg}$ vitamin $\mathrm{E}$ with 50 or $75 \%$ DDGS replacement levels gave the highest percentages of moisture $(80.28 \%)$ and nitrogen free extract $(2.89 \%)$, respectively.

Table 4. Chemical analysis (\%) of whole egg of laying hens as impacted by DDGS levels, vitamin E and their combinations at 42 weeks of age

\begin{tabular}{|c|c|c|c|c|c|c|c|}
\hline \multicolumn{2}{|c|}{ Items } & Moisture & $\begin{array}{r}\text { Total } \\
\text { solids }\end{array}$ & $\begin{array}{c}\text { Crude } \\
\text { protein }\end{array}$ & $\begin{array}{l}\text { Ether } \\
\text { extract }\end{array}$ & \begin{tabular}{|c|} 
Nitrogen \\
free extract
\end{tabular} & $\begin{array}{c}\text { Organic } \\
\text { matter }\end{array}$ \\
\hline \multicolumn{8}{|c|}{ DDGS (\%) } \\
\hline \multicolumn{2}{|l|}{0} & $73.48 \mathrm{c}$ & $26.52 \mathrm{~b}$ & $11.47 \mathrm{~b}$ & $7.96 \mathrm{~b}$ & $2.63 \mathrm{a}$ & $97.58 \mathrm{c}$ \\
\hline \multicolumn{2}{|l|}{25} & $76.42 \mathrm{a}$ & $23.58 \mathrm{~d}$ & $10.71 \mathrm{~d}$ & $7.08 \mathrm{~d}$ & $1.86 \mathrm{~b}$ & $98.25 \mathrm{~b}$ \\
\hline \multicolumn{2}{|l|}{50} & $75.48 \mathrm{~b}$ & $24.52 \mathrm{c}$ & $11.15 \mathrm{c}$ & $7.48 \mathrm{c}$ & $1.48 \mathrm{c}$ & $98.57 \mathrm{a}$ \\
\hline \multicolumn{2}{|l|}{75} & $72.01 \mathrm{~d}$ & $27.99 \mathrm{a}$ & $12.28 \mathrm{a}$ & $8.87 \mathrm{a}$ & $1.38 \mathrm{~d}$ & $98.58 \mathrm{a}$ \\
\hline \multicolumn{8}{|c|}{ Vitamin $\mathrm{E}(\mathrm{mg} / \mathrm{kg}$ diet $)$} \\
\hline \multicolumn{2}{|l|}{0.00} & $75.74 \mathrm{a}$ & $24.26 \mathrm{a}$ & $10.78 \mathrm{~b}$ & $7.42 \mathrm{~b}$ & $1.76 \mathrm{~b}$ & 98.27 \\
\hline \multicolumn{2}{|l|}{200.0} & $72.96 \mathrm{~b}$ & $27.04 \mathrm{~b}$ & $12.03 \mathrm{a}$ & $8.27 \mathrm{a}$ & $1.91 \mathrm{a}$ & 98.22 \\
\hline \multicolumn{8}{|c|}{ DDGS $\times$ Vitamin $\mathrm{E}$} \\
\hline \multirow[t]{2}{*}{0} & 0.00 & $70.96 \mathrm{f}$ & $29.04 \mathrm{c}$ & $12.55 \mathrm{c}$ & $8.71 \mathrm{c}$ & $2.89 \mathrm{a}$ & $97.31 \mathrm{e}$ \\
\hline & 200.0 & $76.00 \mathrm{c}$ & $24.00 \mathrm{f}$ & $10.39 \mathrm{f}$ & $7.20 \mathrm{f}$ & $2.38 \mathrm{~b}$ & $97.84 \mathrm{~d}$ \\
\hline \multirow[t]{2}{*}{25} & 0.00 & $77.13 \mathrm{~b}$ & $22.87 \mathrm{~g}$ & $10.41 \mathrm{f}$ & $6.87 \mathrm{~g}$ & $1.78 \mathrm{c}$ & $98.20 \mathrm{~cd}$ \\
\hline & 200.0 & $75.72 \mathrm{~d}$ & $24.28 \mathrm{e}$ & $11.02 \mathrm{e}$ & $7.28 \mathrm{e}$ & $1.93 \mathrm{c}$ & $98.31 \mathrm{c}$ \\
\hline \multirow[t]{2}{*}{50} & 0.00 & $80.28 \mathrm{a}$ & $19.72 \mathrm{~h}$ & $8.99 \mathrm{~g}$ & $6.02 \mathrm{~h}$ & $1.15 \mathrm{e}$ & $98.75 \mathrm{ab}$ \\
\hline & 200.0 & $70.67 \mathrm{~g}$ & $29.33 \mathrm{~b}$ & $13.31 \mathrm{~b}$ & $8.93 \mathrm{~b}$ & $1.81 \mathrm{c}$ & $98.38 \mathrm{bc}$ \\
\hline \multirow[t]{2}{*}{75} & 0.00 & $74.57 \mathrm{e}$ & $25.43 \mathrm{~d}$ & $11.18 \mathrm{~d}$ & $8.07 \mathrm{~d}$ & $1.23 \mathrm{e}$ & $98.82 \mathrm{a}$ \\
\hline & 200.0 & $69.44 \mathrm{~h}$ & $30.56 \mathrm{a}$ & $13.39 \mathrm{a}$ & $9.67 \mathrm{a}$ & $1.53 \mathrm{~d}$ & $98.34 \mathrm{c}$ \\
\hline \multirow{2}{*}{\multicolumn{2}{|c|}{$\begin{array}{l}\text { SEM }^{1} \\
\text { Two-way ANOVA }\end{array}$}} & 0.62 & 0.62 & 0.26 & 0.20 & 0.10 & 0.09 \\
\hline & & \multicolumn{6}{|c|}{$\mathrm{P}$-value ${ }^{2}$} \\
\hline \multicolumn{2}{|l|}{ DDGS } & $>0.000$ & $>0.000$ & $>0.000$ & $>0.000$ & $>0.000$ & $>0.000$ \\
\hline \multicolumn{2}{|c|}{ Vitamin E } & $>0.000$ & $>0.000$ & $>0.000$ & $>0.000$ & $>0.000$ & 0.560 \\
\hline \multicolumn{2}{|c|}{$\underline{\text { DDGS } \times \text { vitamin } \mathrm{E}}$} & $>0.000$ & $>0.000$ & $>0.000$ & $>0.000$ & $>0.000$ & 0.002 \\
\hline
\end{tabular}

Means in the same column within each classification bearing different letters are significantly different $(\mathrm{P}<0.05$ or 0.01$)$.

'SEM: standard error of the means.

${ }^{2}$ Overall treatment P-value.

\section{Blood chemistry}

Data exhibited in Table 5 showed significant $(\mathrm{P}>0.05$ or 0.01$)$ influences of DDGS inclusion levels on all blood parameters excepting serum content of calcium. Hens fed the $50 \%$ DDGS diet had more concentrations of triglycerides, total cholesterol, LDL-cholesterol and HDL-cholesterol in their blood than those fed control and other DDGS diets. The highest level of serum phosphorous was found in hens fed $75 \%$ DDGS substituted for SBM compared with other diets.

All serum lipid profile components (total cholesterol, LDL-cholesterol and HDLcholesterol) tended to increase ( $\mathrm{P}>0.05$ or 0.01$)$ in a response to dietary vitamin $\mathrm{E}$ supplementation. The interaction between DDGS levels and vitamin E addition had significant $(\mathrm{P}>0.05$ or 0.01$)$ influence on all serum metabolites excepting calcium. 
The combination between 50\% DDGS $\times 0 \mathrm{mg}$ vitamin E gave the highest values of lipid profile constituents including triglycerides, total cholesterol, and HDL-cholesterol. Whilst the highest value of LDL-cholesterol was given by the interaction between $75 \%$ DDGS substitution $\times 200 \mathrm{mg}$ vitamin E/ $\mathrm{kg}$ diet. Additionally, the blood of hens fed $75 \%$ DDGS diets without vitamin E addition had more rich blood with calcium than other treatment groups.

Table 5. Blood metabolites of whole egg of laying hens as impacted by DDGS levels, vitamin E and their combinations at 42 weeks of age

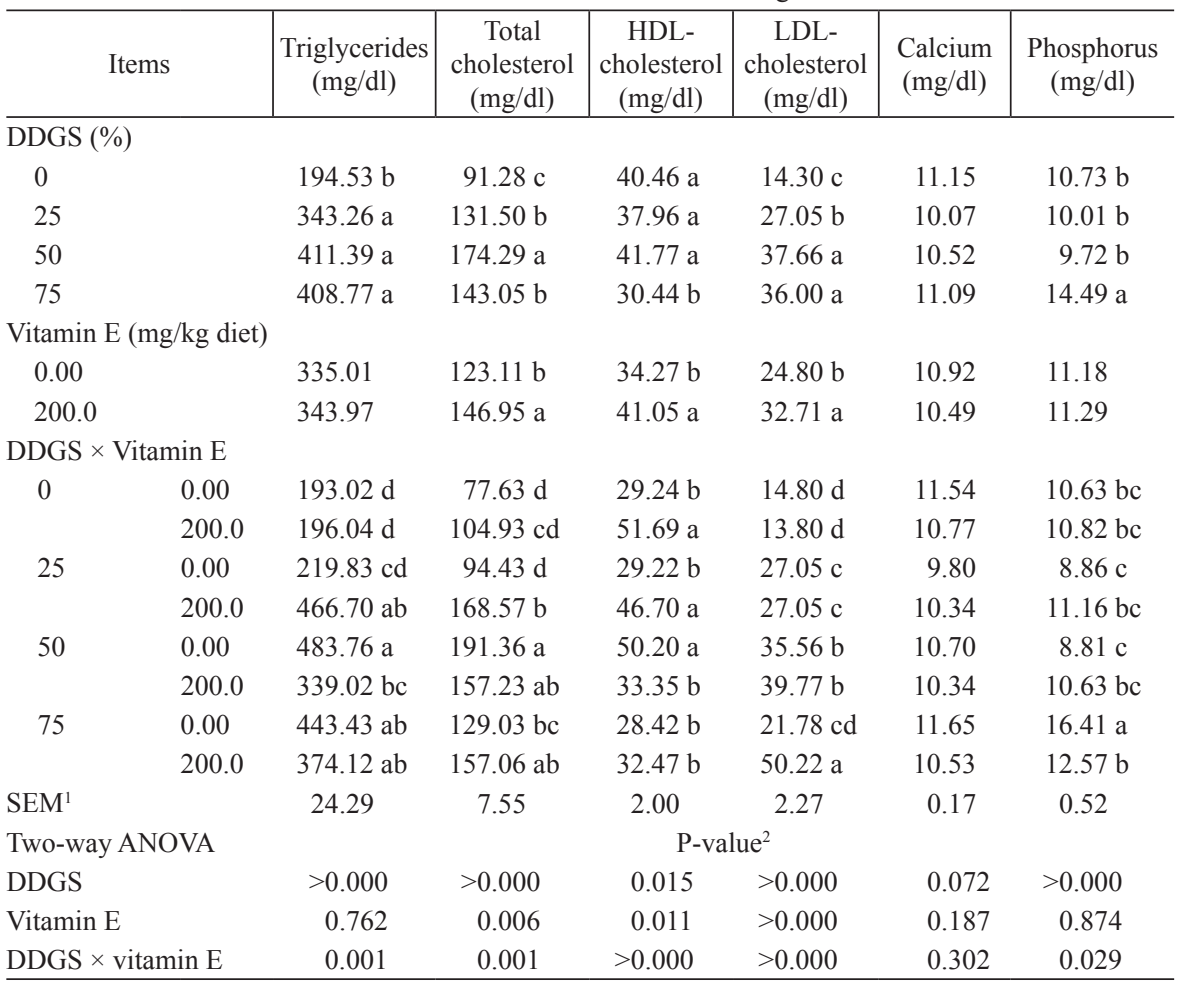

Means in the same column within each classification bearing different letters are significantly different $(\mathrm{P}<0.05$ or 0.01$)$.

${ }^{1}$ SEM: standard error of the means.

${ }^{2}$ Overall treatment P-value.

\section{Discussion}

\section{Hen productive performance}

Decreased laying performance with high level of DDGS in the present study may be referred to the high concentration of fibrous constituents and the low palatability, so the hens were not fully able to meet their amino acid and energy requirements 
(Deniz et al., 2013). Also, this could suggest that non-starch polysaccharides are one of the causes for the negative influence of the $22 \%$ DDGS diet. In agreement with our results, Bregendahl and Roberts (2006) reported that 23-week-old Hy-line layers fed $10 \%$ DDGS diet showed similar laying rate to that of the control $(0 \%$ DDGS diet), favoring the result of our experiment. Further, Roberson et al. (2005) noticed that layers fed diets containing 0, 5, 10, and 15\% DDGS kept their laying rate most of the time but decreased the egg production as the level of DDGS increased at 52 to 53 weeks of age. In contrast, Wu-Haan et al. (2010) and Świątkiewicz and Koreleski (2006) stated that laying hen diets including up to $20 \%$ DDGS did not have any impact on laying rate from 21 to 26 and from 26 to 43 weeks of age, respectively. Moreover, Masa'deh (2011) detected a negative influence on egg production by increasing levels of DDGS from 0 to $25 \%$ for White Leghorn-type hens. The best feed efficiency in our trial was found in the control group, while the worst was given by the $75 \%$ DDGS group compared with other experimental groups. Results reported herein are in line with those of Jiang et al. (2013) who found that the worst feed conversion compared with the 0\% DDGS resulted from feeding $20 \%$ DDGS in the diets. This is consistent with a previous report (Shalash et al., 2010; Deniz et al., 2013). Contrarily, Romero et al. (2012) reported insignificant amelioration in feed conversion (1.98 vs. 2.04) of hens fed $20 \%$ DDGS diets as compared with those fed the DDGS free diets. Our results regarding the effect of treatments on egg production and egg output are in agreement with Grobas et al. (2002), Andi et al. (2006) and Abd El-Hack (2011) who stated that egg number of laying hens was not influenced significantly by different levels of dietary vitamin E. Our results are in disagreement with Aljamal et al. (2008) and El-Mallah et al. (2011), who reported that diets supplemented with vitamin $\mathrm{E}$ had significant improvement in values of egg production when compared to the diets with no supplemental vitamin E. In the present study, it is worth noting that feed efficiency was equal in hens fed diets with or without vitamin E supplementation. This is consistent with previous reports of Friedman et al. (1998) and Bölükbaşi et al. (2007) who reported no presumed effect of vitamin E on feed conversion of laying hens.

\section{Egg quality characteristics}

Graded levels of DDGS were associated with gradual depression in shell percentage and increase in Haugh units (Table 3). The decrease of shell percentage may be due to the consumption of sulfur from sulfur-rich DDGS which may interfere with absorption of dietary calcium from the small intestines (Leeson and Summers, 2001, 2005), thereby reducing eggshell quality, although poultry differ from other species as they can tolerate higher levels of dietary sulfur (Ghazalah et al., 2011). Contrarily, Cheon et al. (2008) reported that no differences in eggshell weight were detected due to DDGS inclusion rates (0, 10, 15 and 20\%) for Hy-line Brown layers with the starch portion of the grain being removed during the fermentation process, the resultant DDGS have a higher concentration of trace elements than corn. This idea is further supported by the work of Jensen et al. (1978) showing that the addition of extra trace elements further increased Haugh unit values. Our findings are in accordance with those of Jensen et al. (1978) who reported that feeding on 10\% DDGS in 
the diet significantly increased Haugh units when compared with a conventional diet. Our results are in conflict with those indicated by Świątkiewicz and Koreleski (2006) and Ghazalah et al. (2011) who reported that the inclusion level of DDGS had no impact on yolk index values. All egg quality criteria were influenced by dietary vitamin E supplementation excepting shell percentage and yolk index. Our results disagree with Metwally (2003) reporting that the effect of vitamin E on egg shape index was insignificant and negligible. Jiang et al. (2013) found that hens fed diets containing $200 \mathrm{mg} / \mathrm{kg}$ of vitamin E had an increased yolk percentage and reduced albumen percentage compared to hens fed $0 \mathrm{mg} / \mathrm{kg}$ of vitamin E. Moreover, the aforementioned authors found no interaction effect between the supplementation of vitamin $\mathrm{E}$ and the inclusion levels of DDGS on egg quality parameters which is converse to our results. Also, Irandoust et al. (2012) detected that supplementation with $250 \mathrm{mg} / \mathrm{kg}$ of vitamin $\mathrm{E}$ had no considerable effect on egg quality.

\section{Chemical analysis of whole egg}

All egg components were significantly influenced by DDGS levels (Table 4). Sun et al. (2015) reported that during the 24-week experimental period, no difference in moisture content of egg yolk among four DDGS treatments was found, and the range of the moisture content of egg yolk was from 48.54 to $48.74 \%$. However, the fat and protein content of egg yolk was affected by the diet with highest DDGS inclusion rate $(50 \%)$. The protein content of egg yolk in $50 \%$ DDGS group was significantly lower than that of the other three groups, and fat content of egg yolk in 50\% DDGS group was considerably higher than that of the other three groups. Fat and protein levels of DDGS diets increased as DDGS inclusion rate increased The difference in fat and protein content of egg yolk may be due to the different fat and protein levels in the DDGS diets. But this effect was only observed in the diet with 50\% DDGS concentration. Jiang et al. (2013) interpreted that increasing DDGS to 10 or $20 \%$ in laying hen diets significantly increased egg crude protein and ether extract compared with $0 \%$ DDGS.

Vitamin E had a positive impact on the majority of egg nutrients. Similar results were gained by Jiang et al. (2013) who found that egg ether extract and crude protein increased when diets were supplemented with $200 \mathrm{mg}$ vitamin $\mathrm{E} / \mathrm{kg}$ diet. They added that the interaction between DDGS levels and vitamin E increased values of egg EE and $\mathrm{CP}$ when compared with diets without vitamin $\mathrm{E}$.

\section{Blood chemistry}

Biochemical blood parameters are usually related to health status. These parameters are good signals of the pathological, physiological, and nutritional status of animals and have the possibility of being used to clarify, the effect of nutritional factors and additives supplied in the diet. Bor-Ling et al. (2011) agreed with our results when reported that the plasma cholesterol was significantly $(\mathrm{P}<0.01)$ increased when 12 or $18 \%$ of DDGS were used in the diets. Contrarily, the same authors found that serum triglycerides were not affected by DDGS levels. In agreement with our findings, Jiang et al. (2013) detected that increasing DDGS to 10 or $20 \%$ in laying hen diets significantly increased $\mathrm{P}$ content in serum compared with $0 \%$ DDGS. 
Vitamin E supplementation increased serum content of total cholesterol, LDLcholesterol and HDL-cholesterol. In agreement with our findings, Jiang et al. (2013) observed that blood HDL and LDL were not significantly influenced by supplemental vitamin $\mathrm{E}$ in laying hen diet, consistent with our results and the previous report of Radwan et al. (2008). Jiang's results were the opposite of ours when reported that dietary supplementation with $200 \mathrm{mg} / \mathrm{kg}$ of vitamin E significantly decreased blood cholesterol. Moreover, El-Sebai (2000), Sahin et al. (2002), Siam et al. (2004) and Abd El-Hack (2011) reported that plasma cholesterol was increased by vitamin E supplementation in laying hen diets compared to the control diet (without vitamin $\mathrm{E}$ addition).

The combination between DDGS and vitamin E had significant impact on all serum metabolites except of calcium. Our findings conflict with Jiang et al. (2013) who reported that the interaction between DDGS levels and vitamin E did not have any significant effect on blood parameters studied i.e. serum cholesterol, LDL, and HDL. Our results disagree with those reported by Ghazalah et al. (2011) who found that the interaction between DDGS levels and vitamin E did not have any significant effect on blood parameters studied (i.e. serum P).

\section{Conclusions}

Based on the aforementioned results, it could be concluded that replacing SBM by 25 or $50 \%$ DDGS did not have any adverse effects on laying performance. Moreover, the vitamin E supplementation improved egg content of crude protein, crude fat, and nitrogen free extract and preserved blood lipids from lipid peroxidation because of its antioxidant activity. The combination between 75\% DDGS replaced SBM with $200 \mathrm{mg}$ vitamin $\mathrm{E} / \mathrm{kg}$ diet achieved the best results regarding nutrient content of eggs.

Conflict of interest. The authors declare that they have no conflict of interest.

\section{References}

AAFCO (2002). Official Publication of the Association of American Feed Control Officials. AAFCO, Oxford.

Abd E1-Hack M.E. (2011). Physiological and immunological responses of some antioxidants on heat stressed laying hens. MSc Thesis, Faculty of Agriculture, Zagazig University.

A b d E 1-Hack M.E. (2015). Enzymes drying to be used in low-cost animal fodder production for existing biotechnology company. PhD Thesis, Faculty of Agriculture, Zagazig University.

A bd E 1 - H a ck M.E., A 1 a g a w a n y M., F a r a g M.R., D ha ma K. (2015 a). Use of maize distiller's dried grains with solubles (DDGS) in laying hen diets: trends and advances. Asian J. Anim. Vet. Adv., 10: 690-707.

Abd E1-Hack M.E., E1-Hindawy M., Attia A., Mahrose K.M. (2015 b). Effects of feeding dried distillers grains with solubles with or without enzyme or vitamin E supplementation on productive performance of Hisex Brown laying hens. Zagazig J. Agriculture Res., 42: $71-79$.

A kiba Y., Jensen L., B arb C., Kraeling R. (1982). Plasma estradici, thyroid hormones, and liver lipid content of laying hens fed different isocaloric diets. J. Nutr., 112: 299-308. 
A lja mal A., Mas a' d e h M., S chei d e le r S. (2008). Vitamin E and selenium supplementation in laying hens. Poultry Sci., 87, p. 50.

Andi M.A., Shivazad M., Pourbakhsh S., A fshar M., Rokni H., Shiri N., Moham$\mathrm{m}$ a d i A., S a l a h i Z. (2006). Effects of vitamin E in broiler breeder diet on hatchability, egg quality and breeder and day old chick immunity. Pak. J. Biol. Sci., 9: 789-794.

AOAC (2003). Association of Official Analytical Chemists Official Methods of Analysis. AOAC, Washington DC.

Aw os any a B., Jos e ph B., O la o s ebikan O. (1998). The effect of age of bird on shell quality and component yield of eggs. Nigerian J. Anim. Prod., 25: 68-70.

B ö l ü k b a ş i Ş.C., E rh a n M.K., K e le ş M.S., K o ç y İ ğ İ R. (2007). Effect of dietary vitamin E on the performance, plasma and egg yolk vitamin E levels and lipid oxidation of egg in heat stressed layers. J. Appl. Biol. Sci., 1: 19-23.

B o r - L in g S., H s u A.L., C h e n Y. (2011). Effects of corn distiller's dried grains with soluble on the productive performance and egg quality of laying hens. Deptartment of Animal Science, National Chia-Yi University, and AGAPE Nutrition Consultant, Taiwan.

B re g e n d a h 1 K., R o b e r t s S. (2006). Nutritional strategies to reduce ammonia emissions from laying hens, Proc. Midwest Poultry Federation Convention, St. Paul, MN. March, pp. 21-23.

Ch e on Y., L e e H., S h in M., J ang A., L e e S., L e e J., L e e B., S o n C. (2008). Effects of corn distiller's dried grains with solubles on production and egg quality in laying hens. Asian-Austral. J. Anim. Sci., 21: 1318-1323.

Deniz G., Gencoglu H., Gezen S., Turkmen I., Orman A., Kara C. (2013). Effects of feeding corn distiller's dried grains with solubles with and without enzyme cocktail supplementation to laying hens on performance, egg quality, selected manure parameters, and feed cost. Livest. Sci., 152: $174-181$.

D un c a n D.B. (1955). Multiple range and multiple F tests. Biometrics, 11: 1-42.

E1- Mallah G., Yas s e in S., A bdel-F at t a h M.M., E1-Gham ry A. (2011). Improving performance and some metabolic responses by using some antioxidants in laying diets during summer season. J. Am. Sci., 7: 217-224.

E 1-S e b a i A. (2000). Influence of selenium and vitamin E as antioxidants on immune system and some physiological aspects in broiler chickens. Egyptian Poultry Sci. J., 20: 1065-1082.

Friedman A., B a rtov I., Sklan D. (1998). Humoral immune response impairment following excess vitamin E nutrition in the chick and turkey. Poultry Sci., 77: 956-962.

G a 11 o - Torres D. (1980). Absorption, blood transport and metabolism of vitamin E. In: A Comprehensive Treatise, LJ Maclin, Marcel Dekker, New York, pp. 170-267.

Ghazalah A., Abd-Els a mee M., Moustafa E.S. (2011). Use of distillers dried grains with solubles (DDGS) as replacement for soybean meal in laying hen diets. Int. J. Poultry Sci., 10: $505-513$.

Grobas S., Mendez J., B ote B.L., De B las B., Mateos G. (2002). Effect of vitamin E and A supplementation on egg yolk $\alpha$-tocopherol concentration. Poultry Sci., 81: 376-381.

Ir and ous t H., S a mi e A., Rahman i H., Edris s M., Mat e o s G. (2012). Influence of source of fat and supplementation of the diet with vitamin $\mathrm{E}$ and $\mathrm{C}$ on performance and egg quality of laying hens from forty-four to fifty-six weeks of age. Anim. Feed Sci. Technol., 177: 75-85.

J e n s e n L., C h a n g C., Wi l s o n S. (1978). Interior egg quality: Improvement by distillers feeds and trace elements. Poultry Sci., 57: 648-654.

J i a $\mathrm{g}$ W., Z h a n g L., S h a n A. (2013). The effect of vitamin E on laying performance and egg quality in laying hens fed corn dried distillers grains with solubles. Poultry Sci., 92: 2956-2964.

L a u d a d i o V., T u fare 11 i V. (2011). Influence of substituting dietary soybean meal for dehulledmicronized lupin (Lupinus albus cv. Multitalia) on early phase laying hens production and egg quality. Livest. Sci., 140: 184-188.

L e e s o n S., S u m m e r s J. (2001). Nutrition of the Chicken. University Books, Guelph, Canada.

Le e s on S., S u m mers J. (2005). Commercial Poultry Production. University Books, Guelph, Ontario, Canada.

M a s a' d e h M.K. (2011). Dried distillers grain with solubles in laying hen and pullet rations. $\mathrm{PhD}$ thesis, Faculty of The Graduate College, Animal Science Department, University of Nebraska-Lincoln. USA. 
Metwally M. (2003). Effects of vitamin E on the performance of Dandarawi hens exposed to heat stress. Egyptian Poultry Sci. J., 23: 115-127.

Naziroglu M., Sahin K., Simsek H., Aydilek N., Ertas O. (2000). The effects of food withdrawal and darkening on lipid peroxidation of laying hens in high ambient temperatures. DTW. Deutsche tierarztliche Wochenschrift, 107: 199-202.

NRC (1994). Nutrient Requirements of Poultry. National Academy Press, Washington, DC.

R a d w a n N.L., H a s s a n R., Q o t a E., F a y e k H. (2008). Effect of natural antioxidant on oxidative stability of eggs and productive and reproductive performance of laying hens. Int. J. Poultry Sci., 7: $134-150$.

Roberson K., Kalbfle is ch J., Pan W., Charbeneau R. (2005). Effect of corn distiller's dried grains with solubles at various levels on performance of laying hens and egg yolk color. Int. J. Poultry Sci., 4: 44-51.

Romero C., Abdallh M., Powers W., Angel R., A p plegate T. (2012). Effect of dietary adipic acid and corn dried distillers grains with solubles on laying hen performance and nitrogen loss from stored excreta with or without sodium bisulfate. Poultry Sci., 91: 1149-1157.

S a h in K., S a h in N., Ond er c i M. (2002). Vitamin E supplementation can alleviate negative effects of heat stress on egg production, egg quality, digestibility of nutrients and egg yolk mineral concentrations of Japanese quails. Res. Vet. Sci., 73: 307-312.

Shalash S., E1-Wafa S.A., Has san R., Ramadan N.A., Mohamed M.S., E1-Gabry H.E. (2010). Evaluation of distillers dried grains with solubles as feed ingredient in laying hen diets. Int. J. Poultry Sci., 9: 537-545.

Siam S.S., Mans our K., El-A nwer E., E1-Warith A. (2004). Laying hens performance, hatchability, immune response and some blood constituents as affected by vitamin $\mathrm{E}$ and selenium supplementation under hot conditions. Egyptian Poultry Sci. J., 24: 483-496.

S ing h R., K u mar J. (1994). Measurement of economic traits. In: Biometrical methods in poultry breeding. Kalyani Publishers, New Delhi, India, pp. 8-12

S n e d e c or G.W., C o c hr an W.G. (1982). Statistical Methods. Iowa State University Press, Ames, USA.

Sun H., Lee E.J., P ersia M.E., Ahn D.U. (2015). Effects of increasing concentrations of corn distiller's dried grains with solubles on chemical composition and nutrients content of egg. Anim. Indust. Rep., 661, p. 52.

Św i ątkiew ic z S., K oreleski J. (2006). Effect of maize distillers dried grains with solubles and dietary enzyme supplementation on the performance of laying hens. J. Anim. Feed Sci., 15: 253-260.

Św iątkiewicz S., A r c zew ska - Włosek A., Krawczyk J., Puchała M., Józefiak D. (2013). Effects of selected feed additives on the performance of laying hens given a diet rich in maize dried distiller's grains with solubles (DDGS). Br. Poultry Sci., 54: 478-485.

Świątkiewicz S., A rczewska-Włosek A., Józefiak D. (2014). Bones quality indices in laying hens fed diets with a high level of DDGS and supplemented with selected feed additives. Czech J. Anim. Sci., 59: 61-68.

Wu-Ha an W., P owers W., Angel R., A p plegate T. (2010). The use of distillers dried grains plus solubles as a feed ingredient on air emissions and performance from laying hens. Poultry Sci., 89: 1355-1359.

Received: 4 XII 2016

Accepted: 16 II 2017 